\title{
COSMOLOGIAS AMERÍNDIAS E FIGURAÇÃO ANIMAL EM QUADRINHOS
}

\author{
Laurent Jérôme ${ }^{1}$
}

Por muito tempo considerada uma forma de expressão juvenil, os desenhos em quadrinhos saíram da categoria de livro para crianças. Foi no meio do Século 20 que reconquistou um público adulto (Grœnsteen, 1987, 2006, 2008, 2011), ao ponto de se inscrever como um estilo de expressão literária e politica que encontrou novo eco com o conceito anglo-saxão de graphic novel (Baron-Carvais, 2007; Dacheux, 2009; Peeters, 2009; Strömberg, 2010; Smith, 1987). Os desenhos em quadrinhos abordando as realidades indígenas são numerosos. Em uma obra síntese, Michael Sheyahshe, originário da comunidade caddo de Oklahoma, realizou um inventário crítico da produção de desenhos quadrinhos que tratam dos indígenas (ver Sheyahshe, 2008). Do selvagem ao bárbaro sanguinário passando pelo traidor incrédulo à_serviço do império ocidental, a imagem do Índio oscila entre clichés, sub-representação e marginalização. Atrás de um personagem de desenho animado se oculta uma história, uma memória coletiva (Brown e Brightman, 1988), das lutas e das resistências. Por exemplo, em março de 2014, DC Comics, uma das principais editoras americanas de livros de desenhos em quadrinhos, anuncia a criação de um novo personagem: Equinox. Equinox foi criado pelo cartunista canadense Jeff Lemire. Ela faz parte da Justice League of Canada, uma equipe de super-heróis, que foi apresentado em maio de 2014, que faz referência à Justice League of America, composta por personagens mais famosos, tais como Batman ou a Mulher Maravilha. Equinox é uma adolescente cri de dezesseis anos. Ela é originaria da comunidade de Moose Factory, em Ontário, localizada na ponta sudeste da Baía James. O poder de Equinox vem da terra e muda com as estações. Jeff Lemire criou esta super-heroína, porque queria romper com a imagem do super-herói masculino branco. Interessado na situação dos indígenas, Jeff Lemire atravessou as aldeias, vilas e comunidades remotas do Meio Norte canadense ao encontro dos seus habitantes e de suas sugestões. Ele se inspirou na vida de Shannen Koostachin, uma jovem ativista crie originiária da comunidade de Attawapiskat, localizada

\footnotetext{
${ }^{1}$ Universidade do Quebec, Canadá. Artigo originalmente publicado em francês na revista RELIGIOLOGIQUES, no 32 , printemps/automne $2015,327-350$
} 
a cerca de 225 quilômetros ao norte de Moose Factory. Esta comunidade foi conhecida, primeiramente, através das mídias em novembro de 2011, quando foram descobertas as condições nas quais viviam seus 2000 habitantes. Este foi o episódio da crise da habitação em Attawapiskat. Cruelmente, faltava à comunidade moradias e as existentes eram intoleravelmente insalubres. As imagens que então circularam, têm pressionado especialmente o Relator Especial das Nações Unidas sobre os direitos dos povos indígenas, James Anaya, que expressou a Stephen Harper sua "profunda preocupação" diante desta situação. Muito antes dessas saídas midiáticas, iniciativas locais foram desenvolvidas por pessoas "comuns". Este é o caso de Shannen Koostachin, que lutou durante anos pelo acesso à educação para os jovens de sua comunidade. Antes da recusa do governo em construir uma nova escola, a antiga tinha sido fechada em 2009 devido à insalubridade. Ela lançou uma campanha de financiamento, juntou-se as crianças e às famílias não-indígenas para apoiar a construção de escolas e fez um discurso reconhecido em um colóquio sobre o direito à educação na Universidade de Toronto, em 2009. No dia 30 de maio de 2010, Shannen Koostachin morreu em um acidente de carro. Hoje, o "Sonho de Shannen" tornouse um grande projeto sobre a segurança e o conforto na escola, e é coordenado pela Sociedade de Apoio à Infância e à Família das Primeiras Nações do Canadá. Alanis Obomsawin, cineasta Abenaki, discute o legado de Shannen Koostachin no filme $\mathrm{Hi}$-Ho Mistahey! Equinox é Shannen Koostachin. Para Jeff Lemire, a super-heroína Equinox é também Theresa Spence, Nina Wilson, Sylvia McAdam, Jessica Gordon, Sheelah McLean, Alanis Obomsawin, Widia Larivière e Melissa Mollen Dupuis, ou seja, todas essas mulheres indígenas engajadas na defesa e na afirmação dos seus direitos.

Outro exemplo: em seu último álbum, Sacco aborda as realidades da reserva indígena Lakota Pine Ridge (Hedges e Sacco, 2012) (ver Figura 1). Sacco desenha e coloca em palavras a vida de diferentes personagens desta comunidade, alternando sua narrativa entre referências históricas e anedotas pessoais. Sacco leva o leitor a refletir sobre o cotidiano de uma reserva autóctone, marcada pela depressão, pelo alcoolismo e o tédio, e a pesada responsabilidade que os seus habitantes parecem carregar coletivamente: a de serem os herdeiros dos fundadores do American Indian Movement, o movimento panameríndio de luta e resistência política nascido em Pine Ridge. 


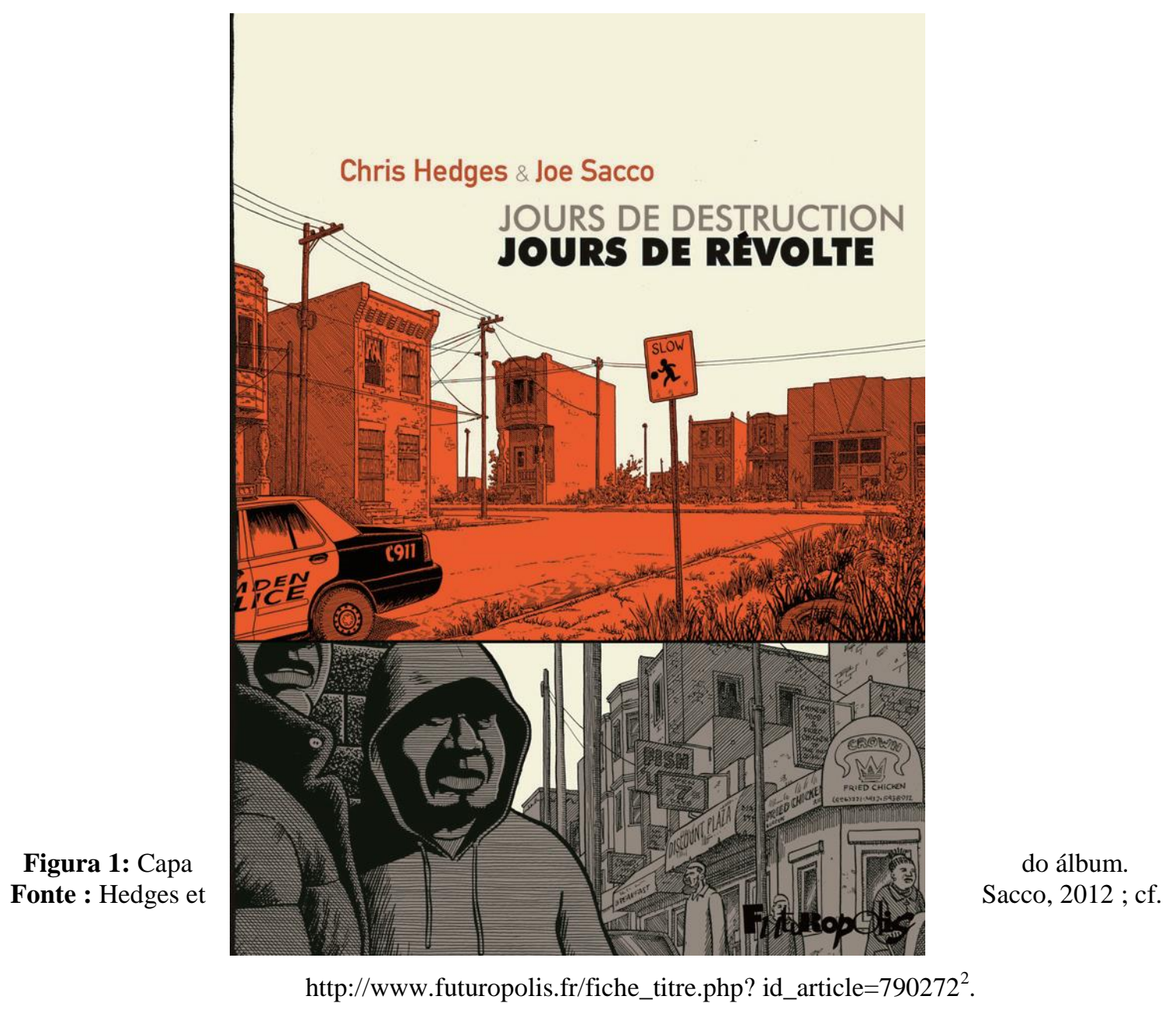

Mas como se trata, mais especificamente, das cosmologias ameríndias nos desenhos em quadrinhos? Este artigo se inscreve, portanto, na continuidade das reflexões atuais sobre as dinâmicas religiosas autóctones das Américas e, em particular, sobre as representações de cosmologias autóctones nas artes. Pretende ser uma primeira exploração, não uma análise realizada a partir de um corpus específico do que um meio como quadrinhos pode revelar imagens que construímos sobre o Outro e, ao inverso das estratégias de apropriação

\footnotetext{
${ }^{2}$ Todos os hiperlinks ativos no 20 de abril de 2015.
} 
da auto-representações pelos povos autóctones. Propomos neste artigo ${ }^{3}$ considerar os quadrinhos como um espaço de criação particularmente revelador das maneiras de conceber as realidades e as cosmologias ameríndias. Nos baseando em quadrinhos realizados tanto por cartunistas autóctones quanto por cartunistas europeus, apresentaremos algumas figurações animais e questionaremos a maneira como os animais, as suas relações com os seres humanos e, mais globalmente, as cosmologias ameríndias são pensadas nos desenhos em quadrinhos. No entanto, começaremos por refletir de forma mais ampla na presença dos animais na nona arte.

\section{Os animais nos quadrinhos: entre animalização e desumanização}

No dia 3 de abril de 2014, o jornal Le Monde evocava o trabalho de Eric Baratay (ver Baratay, 2012), no momento que se ressaltava na França os 100 anos do início da Primeira Guerra Mundial (Vincent, 2014). Evocava-se, em particular, à preocupação de Baratay ao valorizar o ponto de vista animal sobre esta guerra. Quais animais foram mobilizados? Quais eram suas funções? Podemos ter uma ideia de seus sofrimentos? Além do cão, Baratay trabalha a valorização do ponto de vista do cavalo. Tardi (2008) faz também referência em C’était la guerre des tranchées, ao personagem principal, um soldado que vê retornar um cavalo sem seu cavaleiro após uma dura luta: "Os cavalos, os gados que aceitam bestamente carregar em suas costas animais tão perigosos tiveram a sua parte de responsabilidade neste horror imundo, eu disse a mim mesmo em resmungos ... Claro que começo a perder a cabeça! "(Tardi, 1993 2008: 15) Não é humano aquele que acredita ser. Mas surpreendentemente, Baratay se interessa igualmente pelo pombo viajante. Ele explica que é sem dúvida vão pensar se um pombo possa sofrer. Mas é interessante tentar retraçar seus itinerários para entender melhor o que ele pode suportar. Um pouco mais de uma semana após a publicação deste artigo, em 14 de abril de 2014, a França reconheceu a sensibilidade animal (AFP, 2014). De objeto, o animal torna-se, a partir da perspectiva da lei, um ser vivo sensível.

\footnotetext{
${ }^{3}$ Nós gostaríamos aqui agradecer Michèle Cros, Bondaz Julien e Frédéric Laugrand pelo convite e os dois revisores anônimos pelos seus preciosos comentários. Agradecemos também Fonds de Recherche du Québec - Société et culture (FRQSC) pelo apoio financeiro.
} 
Quanto ao desenho animado japonês, os animais recebem um tratamento bastante criativo: sapos, dragões, gatos alados, crocodilos gigantes, louva-deus... Quando se trata de animais em quadrinhos ocidentais vários personagens bem conhecidos, podendo vir a mente: Idefix, Rantanplan, o Gato, Canardo, o gato Felix, Milou, Bill, Garfield... A constatação é óbvia: as representações animais em quadrinhos ocidentais estão geralmente dominados por cães e gatos. Éric Baratay e Philippe Delisle (2012) também dedicaram um livro recente ao cão nos quadrinhos, abordando as múltiplas facetas deste animal, que pode aparecer como nosso próprio trickster. Os personagens e identidades desses personagens nos lembram a função de entretenimento, cínica, humorística ou irônica dos desenhos em quadrinhos. Por exemplo, os animais podem desempenhar um outro papel nos quadrinhos, que revela uma relação muito mais ambígua com o animal ou, mais precisamente, com a animalidade.

Em 1970, Art Spiegelman aposta numa jogada audaciosa (Doherty, 1996; Spiegelman, 19922008 Spiegelman e Mouly, 1988): o desenho em quadrinhos autobiográfico Maus é o primeiro desse tipo a ser reconhecido, não enquanto história para crianças, ou enquanto mito contemporâneo, mas pelo o que ele é: uma obra literária autobiográfica (ver figura 2). Maus recebeu também um Prêmio Pulitzer em 1992 e tornouse o primeiro desenho em quadrinhos a receber tal honra. 


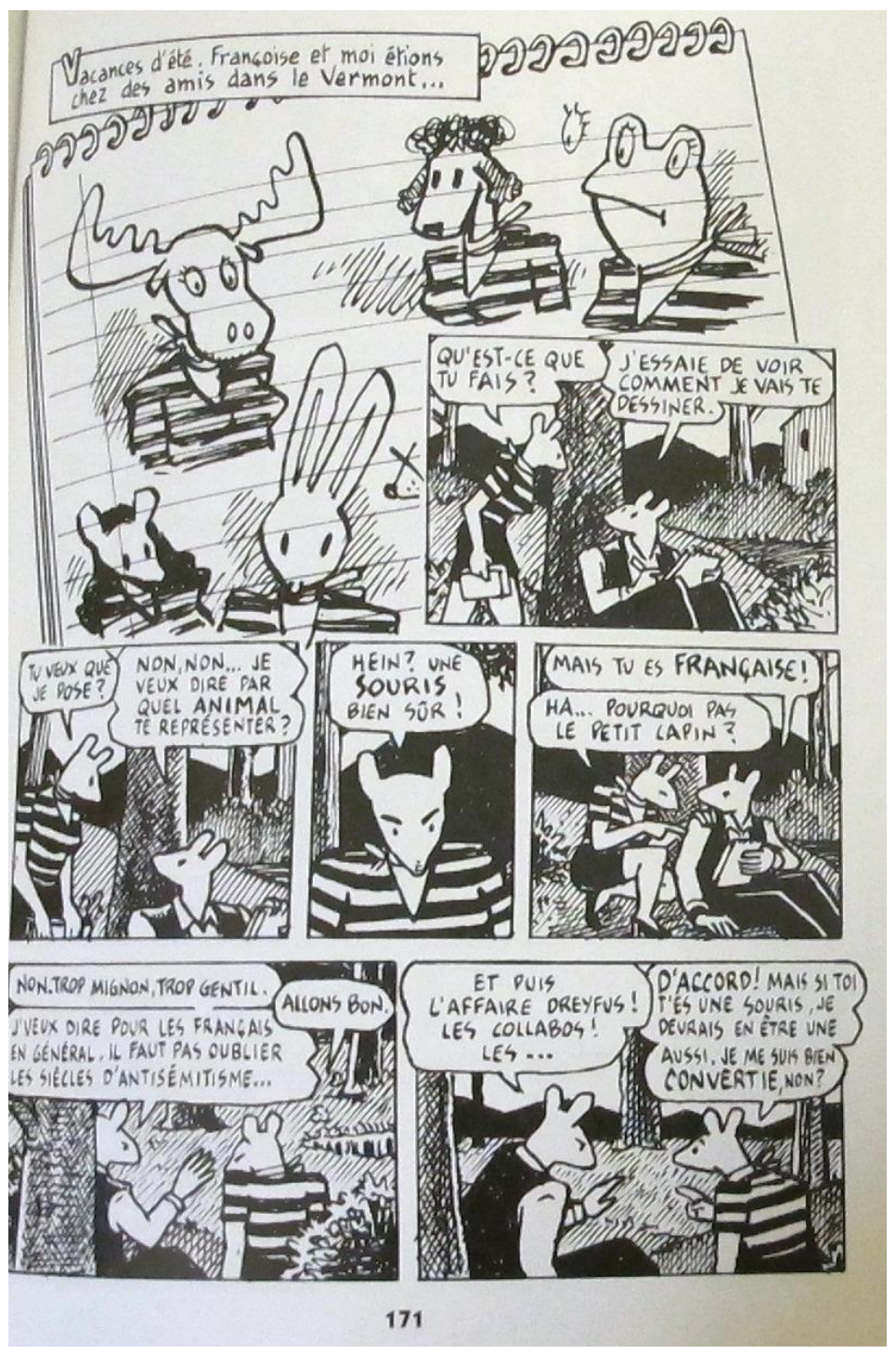

Figura 2: Página extraída de Maus.

Fonte: Spiegelman 1992: 171; cf. http://culturevisuelle.org/luciddreams/archives/188.

Em Maus, Art Spiegelman aborda a Shoah e, por extensão, a sua relação com seu pai Vanek Spiegelman, sobrevivente do Holocausto. Maus é portanto uma dupla narrativa: aquela do pai (Vanek), condenado, que consegue escapar do destino que lhe tinham desenhado os nazistas, e aquela do filho que tenta escapar do controle do seu pai e sobreviver ao sobrevivente. Além dos eventos, lembramos como a relação humano/animal constitui a pedra angular da colocação em imagens dos corpos: os judeus são ratos (Maus = "mouse", um rato), os alemães são os gatos, os franceses são rãs, os americanos, os cães, os 
suecos, alces, os poloneses, porcos, os ingleses, peixes e os ciganos, borboletas. Ao longo desta narrativa sobre o Holocausto, dado a ver pelos pais de Art Spiegelman, Vanek e Anja, os animais permitem transgredir o confinamento racial que caracterizou o genocídio. Vanek e Anja são poloneses. Mas eles também são judeus. Podemos ser Judeu e Polonês ao mesmo tempo? Podemos ser tanto rato quanto porco? É através deste jogo de máscaras que Spiegelman consegue contornar as identidade de seus personagens, para expor o drama do confinamento identitário. Vanek e Anja são ratos, mas usam máscaras para serem suínos e, assim, escaparem dos gatos. O jogo de máscaras permite também a Art Spiegelman brincar com a humanização dos animais, mas sobretudo com a animalização e o "anonimato" dos seres humanos: os nazistas negaram qualquer forma de humanidade aos judeus; Spiegelman os "re-humaniza" em animais. A figuração animal questiona, nestes desenhos animados, a continuidade entre os seres humanos e os animais, o animal aqui representa a negação do rosto humano. Jacques Derrida (2006), mas também Giorgio Agamben (2002) retomam esta questão fundamental da relação dialógica entre a animalidade do humano e a humanidade do animal.

Esta relação animalidade/humanidade no processo de desumanização surge a propósito de outro genocídio, o de Ruanda, cujo vigésimo aniversário foi sublinhado em 2014. Na momento das comemorações, os observadores, jornalistas e críticos literários, em particular, recordaram a obra de Jean-Philippe Stassen, o primeiro cartunista que abordou este genocídio em um desenho em quadrinhos com Déogratias (Stassen, 2000). Déogratias é um jovem Hutu que participou do massacre dos Tutsis e o observou, incluindo os de seus amigos mais próximos, Apollinaire e Bénigne. Enquanto enlouquece após os acontecimentos, a sua aflição é representada por suas transformações em animal cada vez que lembra dos massacres, o adolescente toma os traços de um cão. Ela não se transforma completamente: apenas o rosto assume a forma de bocarra de cão, participando da desumanização do carrasco.

Os exemplos de Maus e Déogratias demonstram como o animal é utilizado para exprimir esta relação, sempre ambígua, que mantemos com a animalidade. Nos desenhos em quadrinhos, o animal adota às vezes os traços e as características do humano (antropomorfização), tanto em termos de intencionalidades e de fisicalidades, retomando os termos de Descola (2005), como nas múltiplas figurações do cão enfatizadas pelo Baratay e 
Delisle (2012). Outras vezes, ele aparece como o reverso do ser humano, como uma entidade que vem figurando o inumano e a loucura humana. Neste caso, é a animalização dos humanos (zoomorfização) que prevalece, como em Maus e Déogratias. Estas figuras animais ilustram certos conceitos de relações que a sociedade ocidental mantém com o mundo animal. Enquanto muitos estudos antropológicos enfatizaram as relações sociais específicas que regem as relações entre os humanos e os animais nas sociedades autóctones (Brightman, 2002; Brown e Brightman, 1988; Descola de 2005, Fausto, 2007; Feit, 1994; Laugrand e Oosten, 2007; Tanner, 1979; Viveiros de Castro, 2009, para citar alguns), o que acontece com as figurações animais e as cosmologias ameríndias nos desenhos em quadrinhos?

\section{Representações das cosmologias ameríndias: forças e poderes do animal}

As figurações animais usadas para representar o lado escuro do ser humano não escapam das histórias em quadrinhos que tratam das realidades autóctones (Baker 1993). Em Muktuk Wolfsbreath, Hard Boiled Shaman: The Spirit of Boo de Terry Laban (2012), o animal protetor do xamã Muktuk é Weasel, uma fuinha alcoólica. Muktuk Wolfsbreath, no entanto, não pode ficar sem seu ajudante animal em suas práticas xamânicas. Weasel lhe retribui bem com a sua proteção e a sua vivacidade de espírito alerta, que não são afetadas pela dependência ao álcool. O leitor pode ver aí uma referência bastante explícita aos problemas sociais exacerbados em relação ao álcool nas comunidades autóctones. Mas também é convidado a refletir sobre as representações do xamanismo siberiano, a "ressentir" o frio ártico e se impregnar por meio do desenho, da profundidade dos sons do tambor xamânico. A abordagem de Laban é decisiva na escolha do tema e no seu tratamento. Apaixonado por museus de sociedade, Laban pesquisou nas obras da antropologia, da história e das ciências das religiões.

Mas quando se fala sobre as representações dos animais nas cosmologias autóctones, outros personagens mais conhecidos destacam-se. Roteirizado e ilustrado pelos cartunistas suíços Job e Derib, As Aventuras de Yakari tem alcançado um sucesso significativo. Os álbuns de Yakari foram traduzidos em mais de vinte idiomas e adaptados para a televisão, com a produção de duas séries de animação em 1983 e 2005. De origem 
Lakota, Yakari incorpora a mobilidade autóctone. Ele encontra, ao perpassar os álbuns e os suas diferentes viagens, todos os animais da América do Norte. Do castor até a coruja, passando pelo bisão, o cisne ou o alce, Yakari tem essa capacidade de se comunicar com os animais. Ele mantém uma relação especial com um companheiro fiel, o cavalo Mini Trovão, que se torna ao longo dos álbuns, o amigo, o confidente e o mediador cultural entre humanos e animais encontrados. Podemos encontrar o lugar central dado ao cavalo em muitos desenhos em quadrinhos dedicados à conquista do Oeste americano. Com Tache de Lune, personagem no desenho em quadrinhos Comanche, Greg e Hermann interrogam os dilemas da integração na sociedade não-autóctone e o apego ao seu grupo. Mas é em outro trabalho de Derib que encontramos a evocação mais convincente de uma representação de cosmologias ameríndias: em Celui qui est né deux fois (Aquele que nasci duas vezes), Derib dedica três álbuns à vida de um Lakota, Pluie d'Orage, e reconstitui o processo de iniciação que o transformara progressivamente em xamã. Baseia-se no trabalho de antropólogos (Frances Densmores, James Taylor e Philippe Jacquin) e de ilustrações de representações gráficas que provêm do Museus Reais de Belas Artes da Bélgica e do Museu da Cultura Popular em Berlim, para apoiar a sua proposta. Cada álbum começa ou termina com referências históricas e antropológicas. Suas pranchetas de desenho tratam da iniciação xamânica, à caça ao bisão, à dança do Sol, pelas quais realizou uma boa etnografia. Por exemplo, no álbum La danse du soleil (1984), seguimos o percurso ritualístico de Pluie d'Orage, (ver Figura 3). O ritual da dança ao sol é representado na relação do ser humano com o bisão e o cavalo, dois animais centrais nas cosmologias das planícies americanas e das pradarias canadenses. 


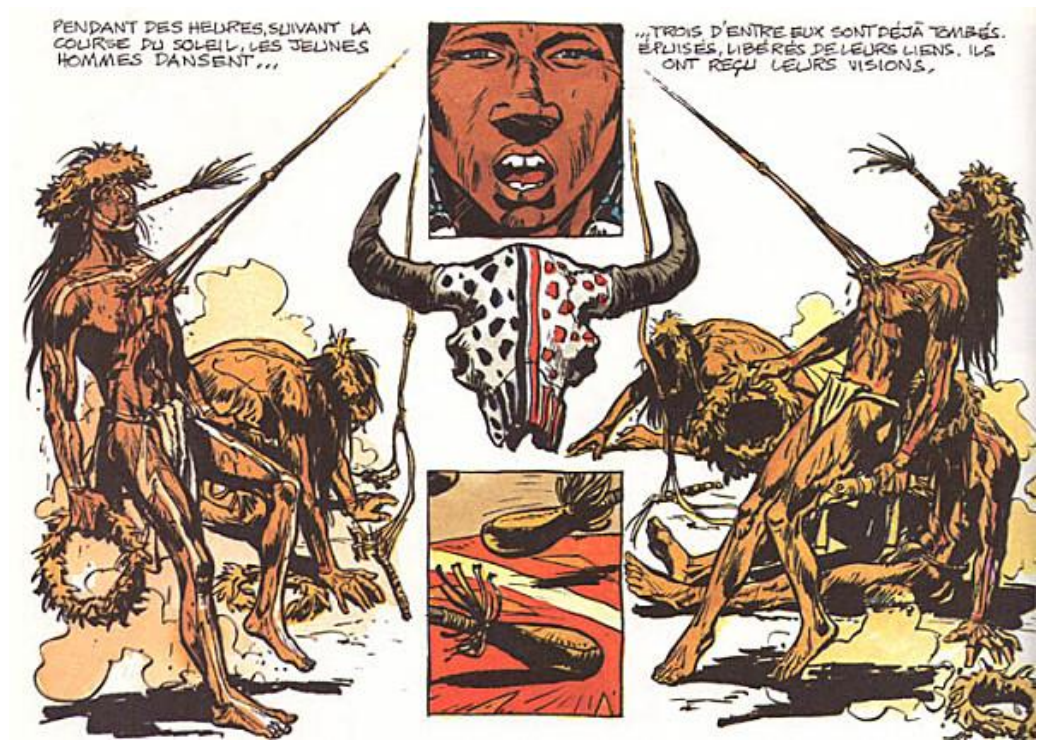

Figura 3: Ilustração da dança do sol

Fonte: Job et Derib, 2002 [1984] : 43 ; cf. http://loinclothed.hostingsiteforfree.com/panels/fotky/all/ celui_qui_est_ne_deux_fois/celui_qui_est_ne_deux_fois.html.

Este lugar do cavalo nas sociedades indígenas americanas inspirou uma exposição no Museu Nacional do Índio Americano em Washington: A Song for the Horse Nation. Horses in Native American Cultures (outubro de 2011-janeiro de 2013). Apesar destes esforços de documentação que têm persistido em outros álbuns de Derib (Buddy Long Way, por exemplo), as representações das cosmologias ameríndias e as figurações animais foram geralmente dominadas, na Europa, pela reprodução do mito romântico do Índio ecologista falando com os animais da mesma forma que com os seres humanos, e pelo tratamento quase sensacionalista das tradições rituais ameríndias.

Essencialmente inspiradas das culturas das planícies e em particular dos Lakotas, as representações das cosmologias ameríndias por cartunistas europeus parecem ir por um mesmo caminho. Os animais são representados pelo o que são em aparência, isto é, animais, e eles são, contudo, dotados de intencionalidades e de propriedades humanas, tais como a fala. Insiste-se sobre os poderes desses animais, capazes de proteger os seres humanos, dos quais eles são geralmente os atributos ou os auxiliares. Mas o desenho em quadrinhos pode tomar uma outra dimensão quando se dá atenção aos temas abordados por cartunistas autóctones. 


\section{A Auto-representação: o animal como um personagem da narrativa}

Red. A Haida Manga de Michael Nicoll Yahgulanaas (2009), The 500 Years of Resistance Comic Book de Gord Hill (2010), ou Trickster. Native American Tales. A Graphic Collection (Dembicki, 2010) são três exemplos de apropriação do desenho em quadrinhos e do discurso sobre si pelos autóctones. Red. A Haida Manga (ver Figura 4) e The 500 Years of Resistance Comic Book são obras políticas, que podem ser associadas aos processos atuais de descolonização.
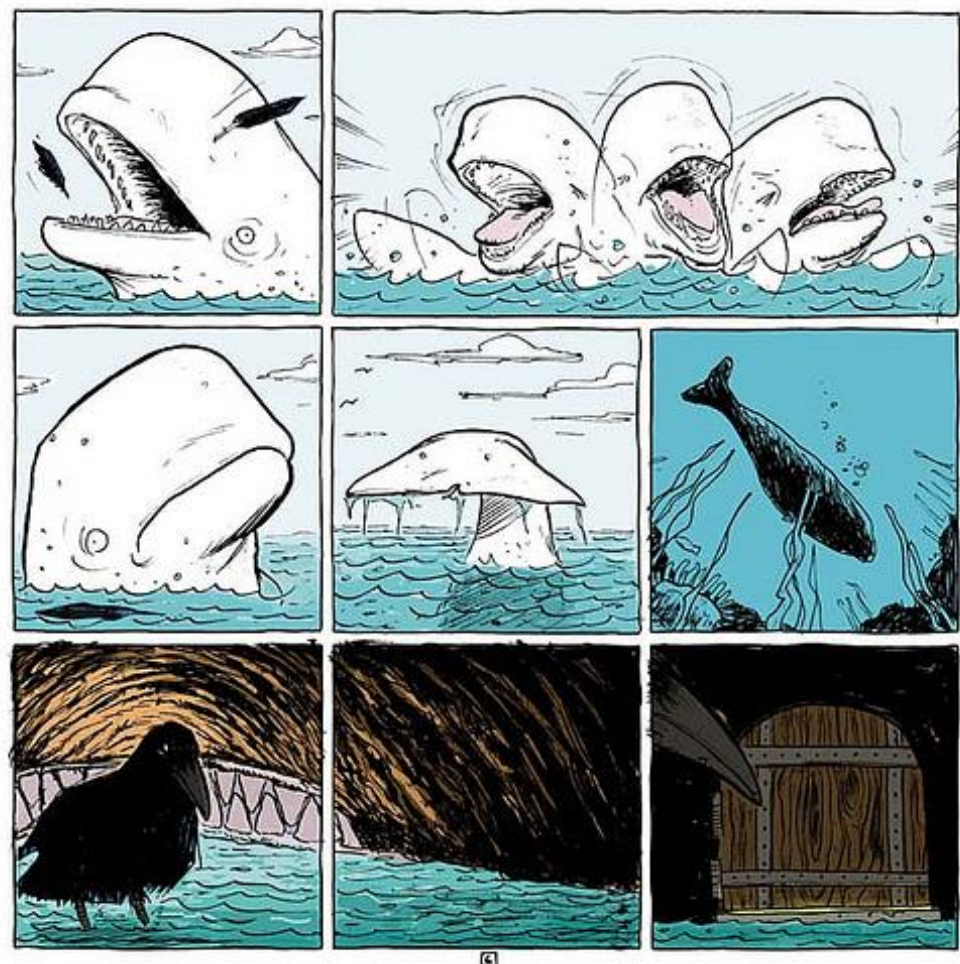

Figura 4: Extraído de Trickster. Native American Tales.

Fonte: Dembicki, 2010 ; cf. http://www.booksandotherthoughts.com/ 2011/02/trickster.html.

Elas evocam as transformações da sociedade Haida (no caso de Red), enquanto The 500 Years volta sobre 500 anos de colonização e resistência autóctone nas Américas. Trickster. Native American Tales. A Graphic Collection em contrapartida, abarca uma longa série de narrativas ilustradas por artistas autóctones, que colocam em cena diferentes tricksters: o coiote, a lebre, o castor ou o corvo (ver Figura 5). 


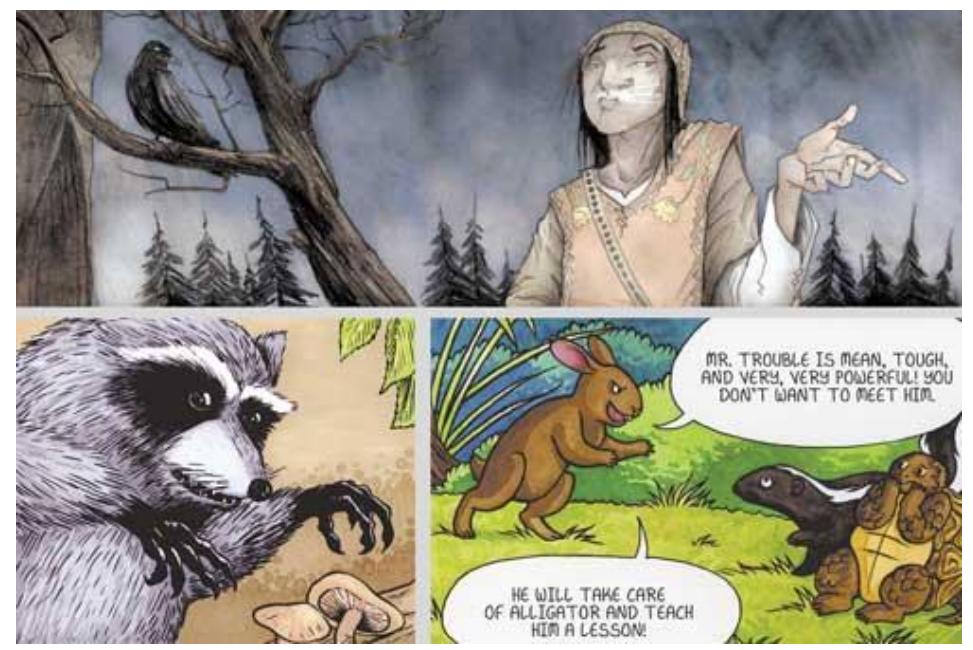

Figura 5. Extraída de Trickster. Native American Tales.

Fonte: Dembicki, 2010: 6; cf. http://www.booksandotherthoughts.com/2011/02/ trickster.html.

O trickster é também o tema de um desenho em quadrinhos Atikamekw, de 1982, no qual são apresentados as aventuras de Wisekatcakw, o carcaju Atikamekw que é encontrado na cosmologia Anishinaabe sob o nome de Nanabozo (ver Servais, 2005). Wisekatcakw não tem realmente uma forma definida. Nem tanto humano nem tanto animal, é um bufão esperto, malandro, transformador da realidade, herói da criação do mundo. Em Opitciwan, o desenho em quadrinhos foi usado para valorizar as peripécias deste herói (Lachapelle, 1982). Na primeira narrativa, descobrimos um ser cuja forma é incerta. Comprido como um homem, tendo os atributos do urso, ficando em pé, Wisekatcakw aborda três abetardas, pedindo-lhes para cantar e dançar com ele. Depois de ganhar a confiança delas e ao mesmo tempo fazendo-as dançar, ele consegue lhes torcer o pescoço. Uma vez desmembradas e arranjadas, Wisekatcakw coloca as três abetardas num buraco que cobre com areia, deixando apenas as pernas de fora. Neste monte de areia, prepara uma fogueira e acende o fogo. Esta técnica de cozimento lhe permitirá dormir e degustar a sua carne de caça na manhã seguinte ao acordar. Ele se coloca em posição, de quatro, se colocando sobre os cotovelos e os joelhos, as costas para o céu, e pede ao seu ânus de o avisar se alguém teve a audácia de se aproximar do rio para roubar suas abetardas. Duas vezes, enquanto Wisekatcakw foi adormecer, o ânus pensa ter visto algo e o alerta imediatamente. Mas por duas vezes, o ânus calculou errado o perigo, confundindo os 
ladrões com espuma e um galho de árvore levada pela correnteza. Para Wisekatcakw, o seu ânus trapaceia. Ele o repreende antes de, finalmente, conseguir dormir. Dois seres humanos depois se aproximam numa canoa. Em silêncio, eles desembarcam na margem, desenterram as abetardas e saiam com o butim precioso sem que o ânus, provavelmente ofendido pelos protestos dos quais foi objeto, alerte Wisekatcakw. De manhã, ele acorda ansioso para saborear sua carne de caça. Ele constata que o buraco está vazio. De raiva, e, provavelmente para dar uma boa lição ao seu ânus, decide colocá-lo nas cinzas ainda fumegantes, o que não deixa de fazer reagir o ânus, tomado por grande dor!

$\mathrm{Na}$ seguinte história, o nosso herói continua a sua viagem com a queimadura nas nádegas, que forma agora uma crosta e que está atacando doravante os bebês perdizes. Ele os aproxima da mesma forma que das abetardas, ganhando a sua confiança, acariciando-os e falando longos elogios. Ele os pega nas suas mãos, os acaricia, ao adotar um tom mais sério lhes diz que não adiantaria comê-los agora por que ainda são pequenos! Ele então coloca os quatro perdizes sob as suas nádegas e defeca sobre eles: "Só com esse cheiro, vou encontrá-los aonde estiverem!", disse rindo. Na linguagem Atikamekw, a mesma palavra é usada para dizer defecar e regar, falando do material fétido liberado pelo gambá. E, assim como o gambá, Wisekatcakw tem o poder de liberar um material fedorento. Porque as perdizes vivem em um território limitado, Wisekatcakw sabe que ele poderá encontrá-las pelo cheiro, porque ninguém mais vai querê-las. Ele continua seu caminho, deixando para trás as perdizes que choram e chamam a sua mãe. Ela chega na hora, reconhecendo de imediato o autor deste truque. "Eu vou lhe dar uma lição", disse ela. No mesmo momento, Wisekatcakw, exausto, encontra uma grande pedra na qual decide tirar um cochilo. A mãe perdiz o localiza e se aproxima em silêncio. Ela decide fazer um barulho ensurdecedor com as suas asas, possível ouvir no final da primavera, o que não deixa de assustar Wisekatcakw e o faz cair da pedra. Na queda, a crosta de sua queimadura é arrancada de sua bunda e permanece presa à pedra. "Quando os humanos viverão aqui", ele disse, "eles chamarão isto de líquen." Este líquen é usado como um curativo para feridas. Ele também pode ser usado para o tingimento. 
Wisekatcakw retoma a estrada, mas a sua ferida está sangrando. Gotas de sangue caem em arbustos: "Doravante, os humanos chamarão essas pequenas árvores "salgueiro vermelho". Os Nehirowisiwok bebiam a casca dessa árvore como um remédio e sua madeira servia para a fabricação de cachimbo. Mais tarde, enquanto a ferida ainda estava sangrando, o pus começou a se formar. De repente, como ele faz o seu caminho entre as árvores da floresta, Wisekatcakw é tomado por uma dor intensa: um galo enganchou no aglomerado de pus da sua bunda. "Quando os seres humanos virem aqui, eles chamarão essa árvore de "érable à épis". Os frutos produzidos por esta árvore, as sâmaras, são da mesma cor que o pus, amarelado. Desde então, os seres humanos conheceram três novas plantas.

As aventuras desses heróis cômicos estão no centro das grandes narrativas autóctones e Trickster. Native American Tales pretende fazer eco a esta unidade na diversidade, evocando, pelo desenho, esta referência às tradições orais de diferentes grupos. A série 7 Generations retoma, por sua parte, a história de uma família crie das planícies do século 19 até hoje, uma história na qual não deixa de abordar a experiência traumatizante dos pensionatos autóctones, mas também o processo de bem-estar no qual se engajem muitas pessoas autóctones hoje. Por exemplo, White Cloud, o personagem principal é confrontado com a visão de uma cobra que saiu de uma nuvem no quarto álbum (ver Figura 6). 


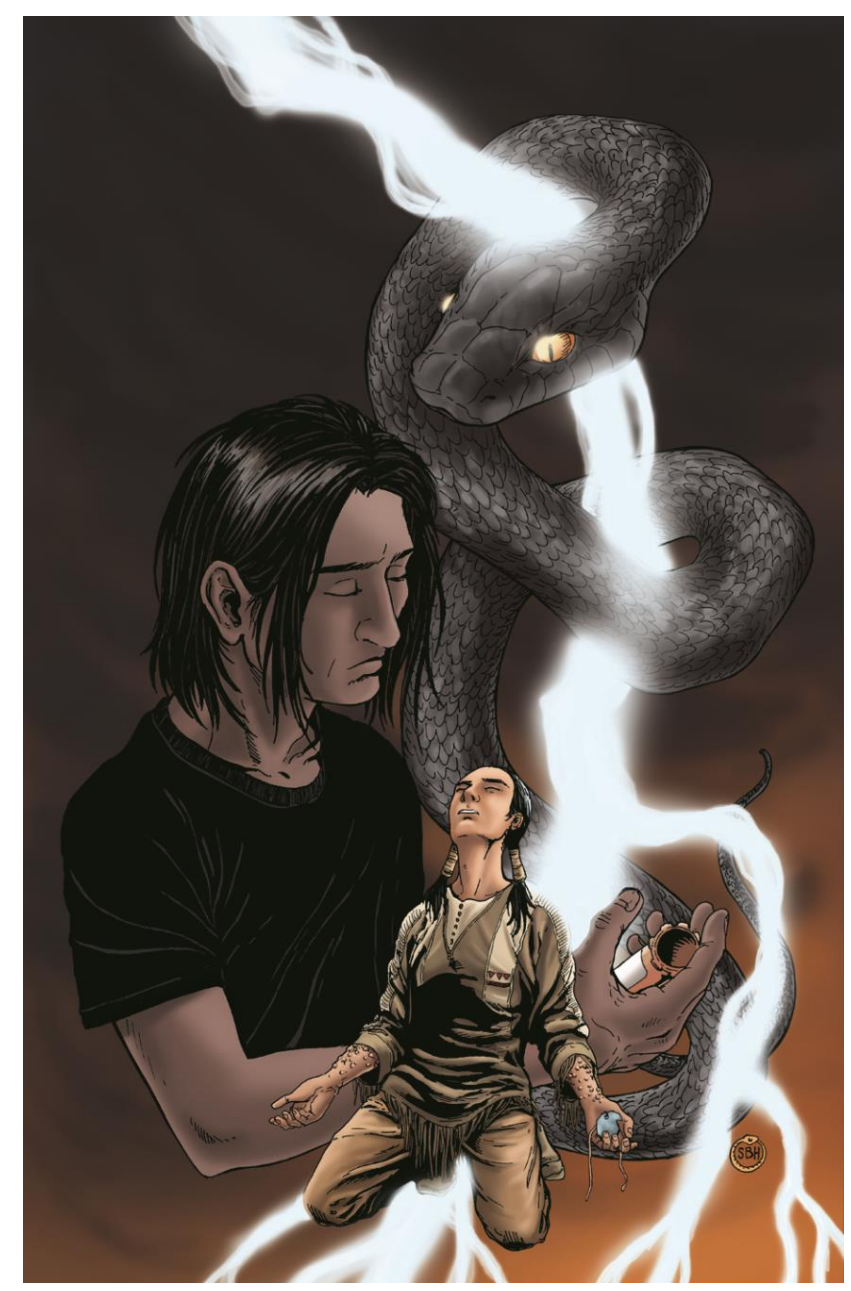

Figure 6: White Cloud confrontado com a visão de uma cobra que saiu de uma nuvem Fonte: Robertson et Henderson, 2012 ; cf. https://sevengenerations.wordpress.com.

A cobra vem aqui representar as interpretações atuais de certas formas de expressão das cosmologias locais, como a narrativa em torno do $7^{\circ}$ fogo que inspirou este desenho em quadrinhos.

No período da Sétimo Fogo, novas pessoas emergirão. Elas retraçarão seu passado para encontrar o que foi deixado para trás. Elas pedirão aos idosos para guiá-las na sua caminhada. Mas muitos desses idosos estarão dormindo. Eles se acordarão para esta nova era e não terão nada a oferecer. Alguns idosos vão ficar em silêncio por causa do medo. Outros permanecerão mudos porque ninguém vai lhes pedir conselho. As novas pessoas deverão tomar cuidado com a maneira de se aproximar dos Sábios. As tarefas das novas pessoas não serão fáceis. Se o Povo permanece forte nas suas pesquisas, o tambor d'água de Midewiwin terá ainda a sua mensagem. Será dada uma escolha entre dois caminhos. Se ele escolhe o bom, em seguida, o Sétimo fogo acenderá o oitavo e último, um fogo eterno de paz, amor, irmandade e fraternidade. Se ele escolhe o 
caminho errado, a destruição virá de volta a eles e causará muita dor e morte sobre toda a terra. (Discurso de Commanda, Maniwaki, agosto de 2004; cf. Commanda [s.d]).

O desenho em quadrinhos, aparece por conseguinte, como uma outra forma de valorizar e transmitir narrativas, profecias, ou ainda, dos mitos de criação, como é também o caso de La terre sans mal de Lepage et Sibran (2008). Este trabalho aborda o mito da criação do mundo dos índios Guarani (Brasil), a "Terra Sem Males", através das pesquisas de um estudante linguista, Éliane Goldshmit, enviada numa missão com os Guarani em 1939 para realizar o primeiro dicionário franco-guarani. O diário de pesquisa é também apresentado no epílogo dos desenho em quadrinhos. Mesmo se não se trata, propriamente falando, da auto-representação, a cosmologia Guarani é aí descrita de maneira muito precisa, vista de dentro, posicionando o jaguar (ver também Clastres, 1974) no coração da história do mito de criação Guarani, cantada por um jovem Guarani para uma Eliane Goldshmit meio desmaiada. Esta narrativa cantada, ele espera, lhe permitirá abrir os olhos e levantar-se novamente:

Ao primeiro canto do mundo, os Jaguares reinavam no coração das trevas. Os homens viviam escondidos nas profundezas da floresta azul. Na sombra dos troncos azuis da floresta azul, Primeira mulher esperava gêmeos: Corpo de Sol e Futura Lua... Ela saiu um dia nos rastros de seu marido e chegou ao acampamento dos Jaguares.

O menino interrompe suas canções "He! Canto para você, Napagnuma para que os teus olhos de velho macaco medroso se abram novamente à luz. He! Um pouco de sangue e ela se encontra dentro da noite..." O menino, em seguida, retoma a história:

Primeira Mulher foi devorado pelos felinos, os gêmeos salvos se tornaram animais domésticos da Avó Jaguar. "Pobres Gêmeos que devem caçar para alimentar os assassinos de sua mãe", cantou a arara na beira da floresta azul... Os gêmeos cavaram uma grande armadilha aonde todos os Jaguares pereceram, com exceção de uma grande fêmea gravida de dois pequenos.

"E depois? "pergunta Eliane, enfim, consciente. "O mundo se tornou ruim. É por isso que buscamos a Terra sem Mal. Bom, tudo bem, termino a meus cantos, mas depois você se levanta, certo?" disse o menino antes de continuar novamente a sua narrativa: 
Ao último canto do mundo, os Jaguares se multiplicaram tanto que Corpo de Sol e Futura Lua partiram para a estada do alto. E sem o Sol, como veremos se aproximando o jaguar? E sem seu irmão Lua, a noite será tão temida. Meu canto se silencia, eu o coloco de volta aonde eu o encontrei.

O menino então se irrita com Eliane "ROOAR! E se tu não abres teus olhos, Avó Jaguar aproximará do teu nariz e o seu ânus que peida e... ". Eliane interrompeu, pronta para se levantar: "Bom, tá bom! Tá bom ! "(Lepage e Sibran, 2008: 33-34).

\section{Conclusão}

Muitos estudos têm mostrado que as sociedades autóctones compartilhavam este fascínio pela arte da representação. Dos sítios rupestres às esculturas inuit, passando pelas pinturas acrílicas dos aborígenes australianos, a figuração das cosmologias autóctones através do mundo todo pode ser expressa de várias maneiras. Ao mesmo tempo, esta arte da figuração é acompanhada por uma outra forma de arte: a de contar. Os desenhos em quadrinhos parecem uma síntese entre a figuração e a transmissão oral. Eles permitem que a forma de uma narrativa se apoie numa série de imagens. A história em quadrinhos se apresenta assim como uma síntese entre a palavra e o visual. Os personagens são figurados; uma história está contada. Nos desenhos em quadrinhos evocados neste artigo, a análise do lugar dos animais e dos seus papeis se torna uma ferramenta para compreender melhor as cosmologias ameríndias. Quando os desenhos quadrinhos são realizados por artistas autóctones, se torna interessante considerar tanto o seu conteúdo quanto a abordagem do artista. Como na narrativa transmitida oralmente, os desenhos em quadrinhos convocam amplamente os registros do jogo, da ironia, da sátira e do humor. Entendemos isso com a história de Wisekedjak, e Roger Bastide se refere a ela, à sua maneira: "[o] riso", escreve ele, "tem uma riqueza semântica, que só se revela quando relacionado à categoria mais ampla do "ruído" com seus dois polos, ligados em ambas as extremidades do tubo digestivo, o riso, que é o peido da boca, e o peido que é o riso do ânus. "(Bastide, 1970: 953). O humor faz parte integramente da mensagem transmitida pelos desenhos e pelos textos dos desenhos em quadrinhos (Eisner, 2009, 2010, 2011; Gabilliet, 2005). Além disso, podemos lembrar que a antropologia se junta ao catolicismo e às cosmologias 
ameríndias Les exploits d'Odilon Verjus de Yann Le Pennetier et Laurent Verron (Delisle, 2011). Odilon Verjus é um missionário católico forte e de barba branca que vive há duas décadas com os papuas da Nova Guiné. Regularmente enviado em missão pelo Vaticano, Odilon Verjus deve resolver vários problemas ao redor do mundo. Ele realiza encontros improváveis com figuras históricas, tais como Agatha Christie, André Gide, os Blues Brothers... ou a antropóloga Margaret Mead (Odilon Verjus: Papous, Le Pennetier e Verron, 2005), que figuram o lugar que a antropologia e os antropólogos podem ocupar nos desenhos em quadrinhos! Hoje, a relação entre antropologia e os desenhos em quadrinhos não pode se restringir à análise dos obras produzidas. Os famosos personagens dos graphic novel se integram cada vez mais ao real através da organização dos ComicCon, os festivais com milhares de admiradores "humanizando" os personagens dos desenhos em quadrinhos, e permitindo novas possibilidades pelo trabalho de campo.

\section{Referências}

AFP. Agence France Presse. 2014. Les députés valident le changement de statut des animaux . Libération, 15 avril. Récupéré de http://www.liberation.fr/ societe/2014/04/15/le-statut-desanimaux-progresse-dans-le-code-civil_997893.

AGAMBEN, Giorgio. L'Ouvert. De l'homme et de l'animal. Traduit de l'italien par Joël Gayraud. Paris: Payot et Rivages. 2002.

BAKER, Steve. Picturing the Beast: Animals, Identity, and Representation. Manchester: Manchester University Press. 1993.

BARATAY, Éric. Le point de vue animal. Une autre version de l'histoire. Paris: Seuil. 2012.

BARATAY, Éric et DELISLE, Philippe. 2012. Milou, Idéfix et Cie. Le chien en BD. Paris: Karthala.

BARON-CARVAIS, Annie. La bande dessinée ( $5^{\mathrm{e}}$ édition). Paris: Presses universitaires de France. 2007.

BASTIDE, Roger. Le rire et les courts-circuits de la pensée . Dans Échanges et communications. Mélanges offerts à Claude Lévi-Strauss, sous la dir. de Jean POUILLON et Pierre MARANDA, vol. 2, p. 953-963. La Haye: Mouton. 1970.

BRIGHTMAN, Robert A. Grateful Prey: Rock Cree Human-Animal Relationship. Regina: University of Regina. 2002 [1973].

BROWN, Jennifer S. H. et BRIGHTMAN, Robert. "The orders of the Dreamed": George Nelson on Cree and Northern Ojibwa Religion and Myth, 1823. Winnipeg: University of Manitoba Press. 1988.

BROWN, Joshua. «Of Mice and Memory ». The Oral History Review, vol. 16, no 1, p. 91-109. 1988.

COMMANDA, William. [s.d.]. Rassemblement à Maniwaki, Québec, Canada. Les peuples amérindiens. L'Aîné William Commanda. Récupéré de http://amerindien.e-monsite.com/pages/laine-william-commanda.html.

CLASTRES, Pierre. La société contre l'État. Paris: Éditions de Minuit. 1974. 
CÔTÉ, André-Philippe. De la caricature et de la bande dessinée. Québec: Éditions Trois-Pistoles. 2003.

DACHEUX, Éric. La bande dessinée : art reconnu, média méconnu. Paris: CNRS Éditions. 2009.

DELISLE, Philippe. Bande dessinée franco-belge et imaginaire colonial. Des années 1930 aux années 1980. Paris: Karthala. 2008.

—. De Tintin au Congo à Odilon Verjus : le missionnaire, héros de la BD belge. Paris: Karthala. 2011.

DEMBICKI, Matt (dir.). Trickster. Native American Tales. A Graphic Collection. Golden: Fulcrum Books. 2010.

DERRIDA, Jacques. L'animal que donc je suis. Paris: Galilée. 2006.

DESCOLA, Philippe. Par-delà nature et culture. Paris: Gallimard. 2005.

DOHERTY, Thomas. «Art Spigelman's Maus: Graphic Art and the Holocaust». American Literature, vol. 68, no 1, p. 69-84. 1996.

EISNER, Will. Les clés de la bande dessinée 1. Art séquentiel. Paris: Delcourt. 2009.

—. Les clés de la bande dessinée 2. La narration. Paris: Delcourt. 2010.

- Les clés de la bande dessinée 3. Les personnages. Paris: Delcourt. 2011.

FAUSTO, Carlos. «Ce que manger veut dire. L'esprit de la prédation en Amazonie ». Dans Nature des esprits et esprits de la nature dans les cosmologies autochtones/Nature of Spirits and Spirits of Nature in Aboriginal Cosmologies, sous la dir. de Frédéric B. LAUGRAND et Jarich G. Oosten. Québec: Presses de 1’Université Laval. 2007.

FEIT, Harvey A. «Dreaming of Animals : the Waswanipi Cree Shaking Tent Ceremony in Relation to Environment, Hunting and Missionization ». Dans Circumpolar Religion and Ecology: An Anthropology of the North, sous la dir. d'Irimoto TAKASHI et Takako YAMADA, p. 289-316. Tokyo: University of Tokyo Press. 1994.

GABILLIET, Jean-Paul. Des comics et des hommes : histoire culturelle des comic books aux ÉtatsUnis. Paris: Éditions du Temps. 2005.

GAGNÉ, Natacha. Being Maori in the City: Indigenous Everyday Life in Auckland. Toronto: University of Toronto Press. 2013.

GRENSTEEN, Thierry. Animaux en cases. Une histoire critique de la bande dessinée animalière. Paris: Futuropolis. 1987.

-. Un objet culturel non identifié. Angoulême: Éditions de l'An 2. 2006.

—. La bande dessinée, mode d'emploi. Bruxelles: Les Impressions Nouvelles. i2008.

- Système de la bande dessinée. Volume 2, Bande dessinée et narration. Paris: Presses universitaires de France. 2011.

HEDGES, Chris et SACCO, Joe. Jours de destruction, jours de révolte. Paris: Futuropolis. 2012.

HILL, Gord. The 500 Years of Resistance Comic Book. Vancouver: Arsenal Pulp Press. 2010 [2007].

JOB, André Jobin et DE RIBAUPIERRE DERIB, Claude. Celui qui est né deux fois. Volume 1, Pluie d'orage. Bruxelles : Le Lombard. 2002 [1984].

LABAN, Terry. Muktuk Wolfsbreath, Hard Boiled Shaman: The Spirit of Boo. Charleston, SC: CreateSpace. 2012.

LACHAPELLE, Claude. Carcajou, Wissekedjawk: les gloutons fripons. Montréal: Appartenance. 1982.

LE PENNETIER, Yann et VERRON, Laurent. Les exploits d'Odilon Verjus: Papous. Bruxelles: Le Lombard. 2005.

LAUGRAND, Frédéric B. et G. OOSTEN, Jarich (dir.). Nature des esprits et esprits de la nature dans les cosmologies autochtones/Nature of Spirits and Spirits of Nature in Aboriginal Cosmologies. Québec: Presses de l'Université Laval. 2007.

LE BRAS-CHOPPARD, Armelle. Le zoo des philosophes. De la bestialisation à l'exclusion. Paris: Plon. 2000. 
LEPAGE, Emmanuel et SiBRAN, Anne. La terre sans mal. Paris: Dupuis. 2008. MCCLOUD, Scott. Réinventer la bande dessinée. Paris: Vertige Graphic. 2006. —. L'art invisible. Paris: Delcourt. 2007.

PEETERS, Benoît. Écrire l'image: un itinéraire. Bruxelles: Impressions nouvelles. 2009.

ROBERTSON, David A. et B. HENDERSON, Scott. 7 Generations: A Plain Cree Saga. Winnipeg: HighWater Press. 2012.

SERVAIS, Olivier. Des Jésuites chez les Amérindiens ojibwas: histoire et ethnologie d'une rencontre, $X V I I^{e}-X X^{e}$ siècles. Paris: Éditions Karthala. 2005.

SHEYAHSHE, Michael A. Native Americans in Comic Books: A Critical Study. Jefferson: MacFarland Pub. 2008.

SMITH, Graham. «From Mickey to Maus: Recalling the genocide through cartoon » [entrevue avec Art Spiegelman]. Oral History, vol. 15, no 1, p. 26-34. 1987.

A Song for the Horse Nation. Horses in Native American Culture. Exposition au National Museum of the American Indian, Washington, du 29 octobre 2011 au 7 janvier 2013. 2011-2013. National Museum of the American Indian. Récupéré de http://nmai.si.edu/exhibitions/horsenation.

SPIEGELMAN, Art. Maus: A Survivor's Tale. My Father Bleeds History I; And Here My Trouble Began II. New York: Pantheon. 1992.

—. Breakdowns: Portrait of the Artist as a Young \%@\&*! New York: Pantheon. 2008.

SPIEGELMAN, Art et MOULY, Françoise. The New Comics. New York: Berkeley. 1988.

STASSEN, Jean-Philippe. Déogratias. Paris: Dupuis. 2000.

STRÖMBERG, Fredrik. La propagande dans la BD : un siècle de manipulation en images. Paris: Eyrolles. 2010.

TANNER, Adrian. Bringing Home Animals: Religious Ideology and Mode of Production of the Mistassini Cree Hunters. Londres: Hurst. 1979.

TARDI, Jacques. C'était la guerre des tranchées. Paris: Casterman. 1993.

—. Putain de guerre! 1914-1915-1916. Paris: Casterman. 2008.

VINCENT, Catherine. "Le 14-18 des animaux », Le Monde, 3 avril. Récupéré de http://www.lemonde.fr/societe/article/2014/04/03/le-14-18-des-animaux_ 4394727_3224.html. 2014.

VIVEIROS DE CASTRO, Eduardo. Métaphysiques cannibales. Lignes d'anthropologie poststructurale. Paris: Presses universitaires de France. 2009.v

VOYER, Cécile. "Histoire de l'art et anthropologie ou la définition complexe d'un champ d'étude ». L'Atelier du Centre de recherches historiques, vol. 6, juin. Récupéré de http://acrh.revues.org/2057. 2010.

YAHGULANAAS, Michael Nicoll. Red: A Haida Manga. Vancouver: Douglas \& McIntyre. 2009.

Tradução: Véonique Isabelle ${ }^{4}$

Revisão: Flávio Leonel Abreu da Silveira ${ }^{5}$

Recebido em: 29/10/2016.

Aprovado em: 06/12/2016.

\footnotetext{
${ }^{4}$ Universidade Federal do Pará, Brasil.
}

${ }^{5}$ Universidade Federal do Pará, Brasil. 